\title{
UNCLOS and territorialization of the seas: the case of Indian and Pacific Oceans
}

\author{
Matías Iglesias ${ }^{1}$ \\ UP - CARI
}

\section{Artículo científico}

Material original autorizado para su primera publicación en el Journal de Ciencias Sociales, Revista Académica de la Facultad de Ciencias Sociales de la Universidad de Palermo.

Recibido: 6 - 3 - 2017

Aprobado: 1 - 8 - 2017

\section{Resumen}

La Zona Económica Exclusiva de 200 millas náuticas de extensión, creada en 1982 por la Convención del Mar, genera conflicto en áreas donde la distancia entre costas nacionales opuestas es menor a 400 millas náuticas y en los mares marginales rodeados por muchos estados y con islas. Este es el caso de los mares marginales de los Océanos Índico y Pacifico. En particular, el régimen de la ZEE ha sido problemático en el Mar de la China Meridional, llevando a algunos autores a preguntarse si ha fortalecido o debilitado de hecho las perspectivas de paz y cooperación. ¿Es realmente la Convención del Mar el problema? Mi propósito aquí es explicar que, en verdad, la Convención del Mar es un hito en el proceso de territorialización del mar. El régimen de la ZEE representa el equilibrio entre presiones opuestas que vienen de los Estados costeros y los terceros estados, generalmente las potencias marítimas; sin embargo, y a pesar del hecho de que, de acuerdo a la Convención del Mar, los Estados costeros ejercen derechos soberanos y no soberanía en la ZEE, se argumentará aquí que los Estados costeros en la práctica se comportan como si sus ZEE fueran su propio territorio soberano. Esto es particularmente cierto en las áreas contenciosas de los Océanos Índico y Pacífico.

Palabras clave: Territorialización, Fronteras, UNCLOS, Océano índio

\section{Abstract}

The 200-nautical-mile Exclusive Economic Zone created by the 1982 UNCLOS regime generates conflict in areas where the distance between opposite national coasts is less than 400 nautical miles and in marginal seas surrounded by many states and with islands. This is the case of the marginal seas in the Indian and Pacific Oceans. In particular,

\footnotetext{
${ }^{1}$ Lic.en RelacionesInternacionales (Universidad de Palermo), Magister en Estudios Geopolíticos (Universidad Carolina, Praga). Miembro del Grupo de Trabajosobre India y Asia del Sur del Comité de Asuntos Asiáticos (CARI).Correoelectrónico: matiasiglesias09@gmail.com
} 
the EEZ regime has proved troublesome in the South China Sea, leading some authors to ask whether it has actually strengthened or undermined peace and cooperation. Does the problem really lie with UNCLOS? My purpose hereby is to explain that, in truth, UNCLOS is a milestone in the process of territorialization of the seas. The EEZ regime represents the balance between the opposing pressures coming from the coastal States and the third states, generally the maritime powers; however, and in spite of the fact that, pursuant to LOS Convention, coastal States enjoy sovereign rights and not sovereignty in the EEZ, it will be argued here that coastal States do in practice behave with respect to their EEZs as if they were their own sovereign territory. This is particularly true of the contentious areas of the Indian and Pacific Oceans.

Key words:Territorialization; Borders; Territory; UNCLOS; IndianOcean

\section{Introduction}

The Asian Rimland is delineated by a series of geographic features: the Arabian Peninsula, the Indian subcontinent; the Malay Peninsula, the Indonesian archipelago, the Philippine archipelago, Taiwan; the Japanese archipelago, the Kurile Islands and the Kamchatka Peninsula. As a result, the Indian and Pacific oceans are subdivided into several marginal seas: the Red Sea, the Persian Gulf and the Arabian Sea; the Bay of Bengal and the Andaman Sea; the Java Sea, the Celebes Sea and the Philippine Sea; the South and East China Seas; the Yellow Sea; and the Seas of Japan and Okhotsk, etc.

The United Nations Convention on the Law of the SEA (UNCLOS), also called the Law of the Sea Convention (LOS Convention), established zones of functional jurisdiction that extend seaward from coastal States baselines: the territorial sea, the contiguous zone, the Exclusive Economic Zone (EEZ) and the continental shelf (LOS Convention, 1982: Arts. 3-16, 33, 55-75, 76-85).

The 200-nautical-mile Exclusive Economic Zone is particularly relevant, for it is neither part of the territorial sea nor part of the high seas, but has a sui generis status; in the $E E Z$, the coastal States enjoy certain specific sovereign rights to explore and exploit its natural living and non-living resources, on the seabed, subsoil and superjacent waters. "Sovereign rights" is a notion distinct from sovereignty (LOS Convention, 1982: Arts. 55-56; Beckman and Davenport, 2012: 7-8). Sovereign rights are not rights deriving from sovereignty but rights of specific functional purpose (Kopela, 2009). The nature of the EEZ regime is critical because it embraces a third of the marine environment. Indeed, all of the important seas and gulfs of the world are composed entirely or mainly of waters within 200 
miles of the coast of some state and the majority of the world's shipping routes pass through them (Beckman and Davenport, 2012: 5-6; Oxman, 2006:839).

The EEZ regime was supported during the negotiations leading to UNCLOS by Latin American states. However, this 200-nautical-mile area was going to generate conflict in areas where the distance between opposite national coasts is less than 400 nautical miles and in marginal seas surrounded by many states and with islands (Song and Tønnesson, 2013:239; Kopela, 2009:2), as is the case of the abovementioned marginal seas in the Indian and Pacific Oceans. In particular, the EEZ regime has proved troublesome in the South China Sea, leading some authors to ask whether it has actually strengthened or undermined peace and cooperation (Song and Tønnesson, 2013:237).

Does the problem really lie with UNCLOS? My purpose hereby is to explain that, in truth, UNCLOS is a milestone in the process of territorialization of the seas: the EEZ regime represents the balance between the opposing pressures coming from the coastal States and the third states, generally the maritime powers; however, and in spite of the fact that, pursuant to LOS Convention, coastal States enjoy sovereign rights and not sovereignty in the EEZ, it will be argued that coastal States do in practice behave with respect to their EEZs as if they were their own sovereign territory. This is especially true of the contentious areas of the Indian and Pacific Oceans.In order to do that, I will proceed as follows:

In Part I, I will introduce certain theoretical concepts from the study of borders, such as borders as markers of territorial rule, borders as membranes, and as defining lines for the formation of identities (Kuzmits, 2013). These are originally meant to help understand land borders, but I will argue that their logic can be applied also to the seas. In Part II, I will describe the phenomenon of territorialization of the seas and explain its relation to the EEZ regime. In Part III, I will present some indicators of how coastal States in the Indian and Pacific Oceans territorialize their EEZs: by introducing "creeping jurisdiction" that restricts freedoms of third States recognized in the LOS Convention, by displaying their capacity to control the space and also by paying careful attentionto naming.In addition to the conclusions, I will comment on how IR theories standin reference to borders and how this reflects on narratives about the Indian and Pacific Oceans.

\section{Borders and territory}

In Borders and Orders in Central Asia..., Bernd Kuzmits explains that the desire for well-defined fixed borders was a direct consequence of the idea of exclusive and uncontested territorial state power that emerged in the nineteenth century (Kuzmits, 2013: 30). Moreover, the concepts of territoriality of rule and sovereignty are bound to borders, because "territoriality is the attempt by an individual or group to affect, influence, or control 
people, phenomena, and relationships by delimiting and asserting control over a geographical area" (Kuzmits, 2013: 38).

Kuzmits(2013) introduces "three salient functions of borders that come out of the narratives of borders and orders": borders as markers of territorial rule, borders as membranes, and borders defining identity lines (34-36).

The boundaries of a state determine the crucial legal distinction between the domestic sphere and the realm of foreign relations. Political borders not only separate but also mediate contacts between social groups. A state's claim on the regulation of contacts and the exertion of power becomes more visible at borders; here, states and their representatives are eager to display their capacity to control a space by fencing off their sovereign territory, by erecting checkpoints and by staffing borders with agents of control. Moreover, Kuzmits (2013) observes that according to cultural theorists, borders are effectively projection screens for theatrical performances, enabling states to assert themselves in front of internal and international audiences at once.

The function of borders as membranes relates to permeability. It is through borders that goods, peoples and ideas are filtered. It is to be noticed that the concepts of borders as markers and membranes are in fact closely interrelated. Because borders mark the threshold between inside and outside, they offer the opportunity to decide which goods, persons and ideas may pass and which are undesirable, at least where the movement can be controlled (Kuzmits, 2013).

Whereas the first two functions relate to physical phenomena, the third brings in the sociocultural dimension and conceptualizes borders as social constructs. Physical borders coincide with cognitive or identity border lines (Kuzmits, 2013: 36).

Even though Kuzmits is thinking of land borders when introducing these functions of borders, it can be argued that coastal states intend to apply an analogous logic in the maritime zones where they can exert jurisdiction, as follows:

1) Coastal States try to monitor and patrol, either with a navy fleet, aircraft, island infrastructure, etc., their adjacent seas in order to exert some degree of control of movement or at least to assert their presence for everyone, both foreigners and nationals (theatrical performance).

2) Coastal States are tempted to pass national legislation requiring, for example, prior authorization for transit, claiming jurisdiction on hydrographic surveys, infrastructure and even customs, and restricting navigational freedom. Particularly contentious is the issue of military-related, or potentially military-related activities.

3) Coastal States are concerned also about their adjacent seas in sociocultural terms. The most obvious example that I will refer to is naming. Argentineans and Chileans call their adjacent seas Argentinean and Chilean sea, respectively. In Asia, by means of 
example, the South China Sea is called East Sea by the Vietnamese. It is easy to see that political implications differ in the case of each name.

\section{The territorial temptation at sea ${ }^{2}$}

Bernard H. Oxman(2006) considers that the history of international law since the Peace of Westphalia is in significant measure an account of the "territorial temptation": the insistent quest for supremacy of the territorial state, based on the assumption that territorial control brings with it control over important sources of sustenance or danger for the state and its people (p. 830).

According to Oxman (2006), whereas the history of the international law of the land can be characterized by the progressive triumph of the territorial temptation, the history of the law of the sea until the mid-twentieth century has seen the advancement of Grotius's thesis of mare liberum. The freedom of navigation reflected the transitory nature of human activity at sea. The Convention on the High Seas (1958) defined the high seas as "all parts of the sea that are not included in the territorial sea or in the internal waters of a State" (Art. 1). This elaboration represented the peak of the Grotian spirit.

However, from the second half of the twentieth century on, the territorial temptation moved seaward. The notion of the tragedy of the commons prompted political pressure on coastal states to find ways to protect local fishing industries facing foreign competition for a limited resource (Oxman, 2006). ${ }^{3}$

At the United Nations Conference on the Law of the Sea (UNCLOS III), which took place between 1973 and 1982, the coastal States, in particular Latin American states, wanted to make the EEZ subject to the sovereignty of the coastal States, but provided that other States had certain rights and freedoms. The maritime powers on the other hand, wanted the zone to be part of the high seas, but provide that coastal States had the sovereign right to explore and exploit the natural resources in the zone. The compromise was to reject both options, and create a sui generis legal regime, whereby coastal States have sovereign rights. The phrase "sovereign rights" makes it clear that the coastal States do not have sovereignty, and do not have residual jurisdiction to regulate matters in the EEZ. Their jurisdiction is limited to those set out in UNCLOS (Beckman and Davenport, 2012: 69).

\footnotetext{
${ }^{2}$ The title of this part is taken and adapted from Oxman (2006).

${ }^{3}$ Cf. Beckman and Davenport(2012):

"The negotiations (for the EEZ) were characterized by the traditional dichotomy between coastal States and the major maritime powers that has always shaped the law of the sea. The historical roots of the EEZ lie in the trend of the coastal States after 1945 to assert rights and jurisdiction over an increasing area of seabed driven by a belief that an abundance of natural resources lay beneath." (p.3)
} 
These provisions notwithstanding, Oxman(2006) observes that the EEZ "is already perceived in quasi-territorial terms" (p.839). ${ }^{4}$ For example, a UNESCO convention expanded the authority of coastal states in the EEZ and on the continental shelf to embrace marine archaeology. This matter "reflects a view of the EEZ as an appropriate vessel for accumulating additional coastal state competences. And each such move increases the territorial perception of the EEZ, which in turn facilitates further territorialization." (Oxman, 2006: 840).

In The "territorialization" of the Exclusive Economic Zone..., ${ }^{5}$ Sophia Kopela(2009) enumerates aspects of expansionist trends by coastal states, which rely on so-called "constructive ambiguities" of the LOS Convention:

1) Military activities / military exercises-maneuvers: some states consider the performance of activities such as military exercises, live weapon tests, etc., as prejudicial to their national security and their resource sovereignty. Hence, they require prior consent for the performance of military activities in the EEZ, or even go further and prohibit them outright;

2) Hydrographic surveys / intelligence-gathering activities: there is disagreement regarding hydrographic surveying and collection of other marine environmental data which are not resource related. The legislation of some states requires the consent of the coastal state for the performance of any kind of research or survey. This issue creates tension as hydrographic surveys are often performed for military purposes related to effective submarine operations, anti-submarine warfare, mine warfare and mine countermeasures;

3) Jurisdiction related to installations / structures: some states have proclaimed their jurisdiction related to all types of installations, structures and devices for any purpose. Highly controversial are military installations, particularly sonar monitoring or surveillance systems;

4) Jurisdiction related to customs: some states have claimed jurisdiction concerning custom-related issues, contrary to the provisions of the LOS Convention, sometimes in the EEZ as a whole, sometimes in specifically designated areas;

5) Jurisdiction related to the Underwater Cultural Heritage;

6) Restriction on the freedom to lay pipelines and cables;

7) Restrictions upon navigational freedoms: some states have attempted to regulate or restrict the entry or passage of vessels through their EEZ.

\footnotetext{
${ }^{4}$ Cf. Beckman and Davenport(2012): "The EEZ has always been perceived in 'quasi-territorial terms." (p.16)

${ }^{5}$ Regarding the term "territorialization", Kopela(2009) explains:

"The term territorialization may not seem appropriate in the sense that states have not raised sovereignty claims over the EEZ; however, they have tried to expand their rights and jurisdiction in such a way so as to assert as much control as possible for the protection of their national interests". (p.2)
} 
All these trends can be related to the conception of borders as markers of territory and as membranes: the passing of legislation related to the control of goods, people, and activities, the monitoring of its observation and its enforcement through security or military forces. The latter occurs in order to assert the presence of the coastal state, not only for third states, but also for the local national audience to see that the state is active. The Indian and Pacific Oceans provide plenty of examples of these trends, as I will show in the following section.

\section{Territorialization in the Indian and Pacific Oceans}

The coastal States of the Indian and Pacific Oceans have taken part in the expansion of territoriality seaward. They have passed plenty of legislation related to jurisdiction.

Bangladesh, India, Malaysia and Pakistan have provisions requiring prior consent for their performance of military activities in their EEZ. Iran has prohibited any foreign military activities and practices, collection of information and "any other activity inconsistent with its rights and interests." China considers the carrying out of military activities as prejudicial to the "peaceful purposes" provision of the LOS Convention. North Korea has established a 50nautical-mile military zone where foreign military vessels and planes are prohibited (Kopela, 2009: Table I).

Regarding hydrographic surveys, Comoros, India, Iran, Malaysia, Mauritius, Myanmar, North Korea, Pakistan and Philippines require the consent of the state for the performance of any kind of research or survey. Moreover, North Korea explicitly prohibits the taking of photographs and any investigation or survey (Kopela, 2009: Table II). China, India, Indonesia, Japan, Maldives, Mauritius, Myanmar, Pakistan, Philippines, Seychelles, Sri Lanka and Yemen have passed legislation related to all types of installations, structures and devices for any purpose and not solely for the purposes established in article 56 (Kopela, 2009: Table III). India and Pakistan have passed legislation concerning custom-related jurisdiction in specifically designated areas in the EEZ (Kopela, 2009: Table IV). China and Iran require authorization for the laying, maintenance or repair of submarine pipelines or cables (Kopela, 2009: Table VI). Finally, Maldives requires prior authorization for the entry of all foreign vessels in its EEZ; India and Pakistan have designated areas in the EEZ where the entry and passage of foreign ships will be regulated by the establishment of fairways, sea-lanes and traffic separation schemes; North Korea has established a 50-nautical-mile military zone where navigation and overflight is to be exercised with the state's consent (Kopela, 2009: Table VIII).

The coastal States have not only passed legislation, but also attempted to monitor and enforce their observance. The South China Sea has historically been the most 
contentious area regarding these aspects. During and after negotiations at UNCLOS III, the coastal states of the South China Sea (in particular Vietnam, China and the Philippines), apart from ratifying the LOS Convention and enacting domestic maritime legislation, have taken a number of actions such as deployment of military troops and occupation of islands (Song and Tønnesson, 2013: 243). For example, in March 1989, China established a Spratly front line headquarters to command a patrol mission and later in August, placed "sovereignty markers" in six maritime features. In 1992, following legislation and oil concessions which were protested by Vietnam, China warned that it would use its navy to enforce the contract and placed more sovereignty markers (Song and Tønnesson, 2013: 244-245). Ever since, China, Vietnam and the Philippines have been constantly observing and accusing each other of exceeding themselves in territoriality assertiveness (Panda, 2016). There are plenty of examples, the most recent of which occurred in January 2016, when China landed a civilian aircraft on Fiery Cross Reef, drawing a sharp reaction from the Vietnamese government. Moreover, there have been several incidents and standoffs between Chinese warships and Vietnamese fishermen, or even between Chinese and Vietnamese warships. ${ }^{6}$

A very famous incident concerning military-related intelligence gathering activities in the South China Sea occurred on $8^{\text {th }}$ March 2009, when five Chinese vessels blocked and surrounded a US surveillance ship, the USNS Impeccable, 75 nautical miles from Hainan Islands. China and the USA continue to have confronting positions regarding these kind of activities. USA conducts so-called Freedom of Navigation Operations (FON, or FONOPS), which involve naval units transiting disputed areas to avoid setting the precedent that the international community has adopted unlawful claims. ${ }^{7}$ In particular, theUSA considers that Chinese sovereignty claims in the South China Sea are not legitimate and that China endangers freedom of navigation. Chinese position is that these "operational assertions" are a provocation and a sign of hypocrisy by the USA, "a non-member of UNCLOS, and a nonrelated party to the South China Sea disputes (...) (who) continuously justifies its intercessions into the dispute as a protector of UNCLOS" (Colonel Xiaoqin Shi, 2015; Bo, 2015). However, there is also the argument that FONOPS have long been a part of US foreign policy and should not be seen as a sign that diplomacy has been set aside (RappHooper, 2015). ${ }^{8}$ The controversy between China and the US on this matter is perhaps the current clearest example of the traditional dispute between a coastal state and a maritime power regarding freedom of navigation.

\footnotetext{
${ }^{6}$ For a timeline of events in the East and South China see for example http://www.cnas.org/flashpoints/timeline.

${ }^{7}$ See http://2001-2009.state.gov/t/pm/iso/15962.htm.

${ }^{8}$ See also Klein and Rapp-Hooper (2015), Odom (2015).
} 
This kind of incidents is not exclusive of the South China Sea, though. In 2001, the Japanese Coast Guard pursued a North Korean spy vessel in its EEZ. Japan protested against similar activities performed by China. India has also protested against the USA for oceanographic survey operations related to military data gathering (Kopela, 2009:6).

The Asian coastal States continue to make preparations to enhance their monitoring and control capacities. China is building a second aircraft carrier, the first to be built indigenously (Tiezzi, 2016). Vietnam commissioned two new Russian-made Kilo-class diesel-electric submarines and revealed an indigenous high-altitude long-endurance unmanned aerial vehicle (UAV) for patrolling the South China Sea (Gady, 2015a; 2015b). The Philippines received recently one Japanese and four US patrol vessels to enhance its navy's capacity to patrol and enforce fisheries-related laws (Parameswaran 2015a, 2015b). Indonesia has made plans to create by 2024 a modernized green-water navy capable of undertaking an array of missionswithin the immediate regional waters while having limited ability to project force into distant waters (Singh, 2015), as part of its Global Maritime Fulcrum vision (Widodo, 2014).

India, on its part, has revealed a new Indian Maritime Strategy (Singh, 2015) and a plan for civilian and military development of Andaman and Nicobar Islands (ANI), the aim of which is to turn ANI into a hub of repair ship industry, boost tourism potential and build it up in military terms (Arora, 2015: Pandit, 2015; Roy, 2015). ${ }^{9}$ Sanat Kaul, former administrator of the islands, has published almost at the same time a book describing the policies to be pursued, also and especially concerning soft power and the image of India, with the purpose of changing the perception of both Indians and foreigners with regard to India's reach in the Indian Ocean (Kaul, 2015).

The importance of borders as social constructions can also be observed in reference to the names of seas and islands, which have political implications. It is easy to imagine why nationals of Iran, India, China, the Philippines and Japan are eager to see that international cartography keeps the names of "Persian Gulf," "Indian Ocean," "South and East China Seas," "Philippine Sea" and "Sea of Japan," respectively. However, since the 1960s, due to the rivalry between Iran and the Arab states, along with the emergence of Arab nationalism, some Arabian states have preferred to speak of the "Arabian Gulf" (Abedin, 2004; Bosworth, 1980). The South China Sea has traditionally been named "East Sea" by the Vietnamese. Recently, some Philippine government agencies, following the lead of President Aquino after an escalation on the Spratly Islands disputes, started using the neologism "West Philippine Sea" to refer to the South China Sea (Quismundo, 2011). The Vietnamese Nguyen Thai Hoc Foundation (NTHF) has launched an initiative to rename the sea as "Southeast Asia Sea," to

\footnotetext{
${ }^{9}$ See also Watson (2015).
} 
make clear that the sea is not restricted to a specific country. ${ }^{10}$ There is also a naming dispute on the Sea of Japan. South Koreans prefer to call it "East Sea" and North Koreans "East Sea of Korea" (The Issue of the Name of the Sea of Japan, 2015). All these disputes refer to the notion that borders define lines for the formation of identities along the binary distinction between "us" and "them".

\section{Conclusions}

Bernard H. Oxman, upon commenting the LOS Convention, makes the observation that international law at any given time represents an equilibrium between opposing pressures (Oxman, 2006: 850).

In this context, when asking whether UNCLOS has enhanced cooperation or contributed to further conflict, it is important to understand that UNCLOS is the result of two opposite forces: a territorializing pressure emerging from the coastal states and an internationalizing pressure that vows for freedom of navigation and global governance of the commons.Where the seas are open as in South America, the EEZ is relatively unproblematic. The Indian and Western Pacific Oceans, however, are likely to present numerous conflicts.

These opposing pressures are also reflected in IR approaches to the study of borders. Both Realism and Liberal Institutionalism start from state-oriented stances. However, whereas Realists focus on the production of borders, i.e. on boundary demarcation and border management within the wider context of competitive relationships between rivalling neighbors that struggle to survive, Liberal Institutionalism is more concerned with the question of how to overcome obstacles to transactions and cooperation, and have offered models of integration, international interaction and economic interdependence (Kuzmits, 2013: 30, 35).

The different security constructions or discourses lie in the interphase between theory and policy. Rumley, Doyle and Chaturvedi (2012) explain how the regional security debate in the Indo-Pacific is framed within competing regional (maritime) security constructions: conservative commentators refer to an Indo-Pacific Region, a realm of nationalism where hard power and traditional security play the leading role, and policy is conducted by Departments of Defense; liberal commentators refer to an Indian Ocean Region, a realm of pan-regionalism where soft power matters, diplomacy plays the main role and policy is conducted by Foreign Affairs departments; there is also a middle ground

\footnotetext{
${ }^{10}$ See the website of the Nguyen Thai Hoc Foundation (http://www.nguyenthaihocfoundation.org/index en.php).
} 
construction, the so-called East Indian Ocean, where both liberal and conservative commentators refer to limited diplomacy and both soft and hard power interact.

Only time will tell whether the balance breaks in favor of one of the opposing pressures, and the issue is embedded in a wider framework of discussion about the future of sovereignty and territoriality.When it comes specifically to maritime territoriality and maritime security, the Indian and Pacific Oceans will prove a crucial region to observe future developments. This is due to the particular geographical features of the Asian Rimland, which provide the Indian and Pacific Oceans with enclosed marginal seas and generate disputes like no other region in the world.

\section{Bibliography}

Abedin, M. (2004, December 9). All at sea over the "Gulf". Asia Times.

Arora, R. (2015, September 26). Modi government's Rs 10,000 crore plan to transform Andaman and Nicobar Islands. The Economic Times.

Beckman, R. (2013). The UN Convention on the Law of the Sea and the Maritime Disputes in the South China Sea. The American Journal of International Law, 107(142), 142163.

Beckman, R., \& Davenport, T. (2012). The EEZ Regime: Reflections after 30 Years. LOSI Conference Papers.

Bo, H. (2015, November 17). The Hypocrisy of US Freedom of Navigation Operations in the South China Sea. The Diplomat.

Bosworth, C. E. (1980). The Nomenclature of the Persian Gulf. In A. J. Cottrell (Ed.), The Persian Gulf States: A General Survey. Baltimore, Maryland: Johns Hopkins University Press.

Cole, B. D. (2008). Sea Lanes and Pipelines: Energy Security in Asia. Westport CT: Praeger Security International.

Gady, F.-S. (2015a, August 6). Vietnam Commissions Two New Subs Capable of Attacking China. The Diplomat.

Gady, F.-S. (2015b, December 28). Vietnam Reveals New Drone for Patrolling the South China Sea. The Diplomat.

Kaul, S. (2015). Andaman and Nicobar Islands. India's Untapped Strategic Assets. New Delhi: Pentagon Press. Institute for Defence Studies \& Analysis.

Klein, A., \& Rapp-Hooper, M. (2015, October 23). Freedom of Navigation Operatoins in the South China Sea: What to Watch For. Lawfare.

Kopela, S. (2009, April 1-3). The "territorialisation" of the Exclusive Economic Zone: Implications for maritime jurisdiction. Paper presented at the 20th Anniversary Conference of the International Boundaries Research Unit on the State of Sovereignty, Durham University, United Kingdom.

Kuzmits, B. (2013). Borders and Orders in Central Asia. Transactions and Attitudes between Afghanistan, Tajikistan and Afghanistan. Nomos. 
Lean Collin, K. S. (2015, August 18). Tough Times Ahead for the Indonesian Navy. The Diplomat.

Odom, J. G. (2015, October 31). Why US FON Operations in the South China Sea Make Sense. The Diplomat.

Oxman, B. H. (2006, October). The Territorial Temptation: A Siren Song at Sea. The American Journal of International Law, 100(4), 830-851.

Panda, A. (2016, January 3). Vietnam Protests as China Lands Civilian Aircraft on Newly Constructed Spratly Airstrip. The Diplomat.

Pandit, R. (2015, May 7). India to slowly but steadily boost military presence in Andaman and Nicobar Islands. The Times of India.

Parameswaran, P. (2015a, August 15). Japan Gifts Vietnam Patrol Vessel Amid South China Sea Tensions. The Diplomat.

Parameswaran, P. (2015b, September 8). US to Deliver Four New Patrol Vessels to the Philippines. The Diplomat.

Quismundo, T. (2011, June 13). South China Sea renamed in the Philippines. Asia One News.

Rapp-Hooper, M. (2015, October 12). All in Good FON. Foreign Affairs.

Roy, V. C. (2015, October 5). Indian islands to be developed under Swiss challenge model. Business Standard.

Rumley, D., Doyle, T., \& Chaturvedi, S. (2012, April). Securing the Indian Ocean? Competing Regional Security Constructions. Indo-Pacific Governance Research Centre. Policy Brief(3).

Shi, X. (2015, October). UNCLOS and China's Claim in the South China Sea. Indo-Pacific Strategic Papers.

Singh, A. (2015, December 28). India's Emerging Indian Ocean Strategy. The Diplomat.

Smith, J. M. (2014, 18 March). Andaman and Nicobar Islands: India's Strategic Outpost . The Diplomat.

Song, Y.-h., \& Tønnesson, S. (2013). The Impact of the Law of the Sea Convention on Conflict and Conflict Management in the South China Sea. Ocean Development \& International Law, 44(3), 235-269.

The Issue of the Name of the Sea of Japan. (2015, May 15). Retrieved from Ministry of Foreign Affairs of Japan: http://www.mofa.go.jp/policy/maritime/japan/index.html

Tiezzi, S. (2016, January 1). Confirmed: China is Building a Second Aircraft Carrier. The Diplomat.

United Nations Convention on the Law of the Sea. (1982).

Watson, S. (2015, November 16). Will India Truly Start "Acting East" in Andaman and Nicobar? Asia Maritime Transparency Initiative.

Widodo, J. (2014, November 14). The seas should unite, not separate us. The Jakarta Post. 